\title{
MACROBENTHIC COMMUNITY STRUCTURES OF THE OFFSHORE AREA OF MIMIKA DISTRICT, PAPUA
}

\author{
Woro W. Kastoro ${ }^{2 *}$, Amiruddin', A. Aziz ${ }^{2}$, I. Aswandi ${ }^{2}$, I. Al Hakim², Deky Lala1, and Gesang Setyadi ${ }^{1}$ \\ 1) PT Freeport Indonesia, Timika, Mimika district, Papua \\ 2) Research Center for Oceanography - Indonesian Institute of Sciences, \\ Jl. Pasir Putih I, Ancol Timur, Jakarta 11048 \\ *e-mail:woro_kastoro@fmi.com
}

\begin{abstract}
The study on macrobenthic community structures was carried out in the offshore area of Mimika district, Papua in 2005. Steep mountain slopes and some of the highest rainfall rates in the world, have generated tremendous sediment loads that have settled in the alluvial plain and been carried out into the estuaries and the Arafura Sea, creating a massive area of deposited natural sediments.

The objective of this study was to determine how the benthic community structures of the offshore area (Arafura Sea) changes as a result of environmental conditions. To accomplish the objective, samples were collected from 40 stations which were divided into 4 contours (layers) of water depth, i.e. 5, 10, 20 and 40 m. Stations of each contour depth were established perpendicular to the river mouths of Mimika district. The results showed the bottom sediments were mostly silt-clay fractions except the deeper area ( $40 \mathrm{~m}$ depth) which was dominated by very fine sand fraction. Diversity indices, Shannon index ( $\left.\mathrm{H}^{\prime}\right)$ and Pielou's evenness (e) index ranged from 1.00-3.50 and 0.20-0.92 respectively. These indices tended to increase in the deeper areas. In total 266 species of macro-benthos were collected from the study area. Contrary to this, the densities tended to decrease in deeper areas with the range of $195.00-4110.00$ individualsm $^{-2}$. Polychaetes was the the dominant group, $50.80-71.80 \%$ of the total family of macrobenthos. Among the macrobenthos, there were some families and group of taxa which had high densities such as Sipuncula, Nemertea and crustaceans including Ampeliscidae, Gammaridae and Israeidae. Among the polychaete group were the families Spionidae, Owenidae, Sternaspidae, Cossuridae, Capitellidae, Nephtyidae, Magelonidae and Pilargidae. Based on density, macrobenthos of the study area shows relatively high production. High rates of sedimentation of Ajkwa estuary does not influence the structure of macrobenthic communities in the offshore area.
\end{abstract}

Keywords: Benthos, Offshore, Mimika, Papua, Indonesia

\section{INTRODUCTION}

The study of macrobenthic community structures was carried out in the offshore area of Mimika district, Papua province in 2005. The highland rivers of Papua bring large sediment loads from the mountain to the lowland and then to the estuaries and Arafura Sea due to the steep mountain slopes and high rainfall rates (some of the highest rainfall rates in the world) (Collison et al., 1997). The coastal region of Mimika is classified as a shallow, windy, high energy area with tidal variation greater than 3 meters. The straits of the southern coast of Papua near
Amamapare harbor are influenced by rivers carrying fine mud (silt and clays) and sand into the sea for several kilometers and creating deposits of 3 to 4 meter depths.

Benthic community structure has been most recently studied as interdisciplinary studies of anthropogenic effects on marine ecosystem. Many characteristics of benthic assemblages make them useful indicators, the most important of which are related to their exposure to stress and the diversity of their response (Bilyard, 1987). The structure of benthic assemblages also reflects natural variation relating to salinity, sediment type, latitude and depth (Heip and Cracymeersch, 1995). 
The study was carried out in 2005, in conjunction with the monitoring program conducted by PT Freeport-Indonesia. The objective of this study was to determine the benthic community structures in the offshore area (Arafura Sea) of Mimika district in relation to the contours of water depth and sediment types.

\section{MATERIALS AND METHODS}

The study area is the offshore waters of Mimika district, located in the western half of Papua (Fig. 1). The coast is open to the Arafura Sea and subjected to moderate wave and current. Five large estuaries (Tipuka, Ajkwa, Minajerwi, Mawati and Otakwa) and two smaller estuaries (Kokonau and Kamora), discharge their water to the coastal waters. Generally, the rivers in this area flow in a meandering pattern forming numerous distributaries, lowland swamps and estuaries as they approach the sea.

\section{Method of Sampling}

The survey was carried out in November (2425), 2005 using a catamaran vessel, Akapoma. Transects were established perpendicular to the beach with one transect corresponding to each of the rivers, except for the Kokonau, Ajkwa and Otakwa rivers where two transects for each river were established. Along each transect a station was established at a contour depth of 5, 10, 20 and $40 \mathrm{~m}$. The rivers included the Kokonau (Co), Kamora (K), Tipoeka (T), Ajkwa (A), Minajerwi (MI), Mawati (MA) and Otakwa (OT). These overall extent from the first to the last transect was about $25 \mathrm{~km}$ (Fig. 1).

\begin{tabular}{|c|c|c|c|c|}
\hline & \multicolumn{4}{|c|}{ Contour of water depth } \\
\hline River & $\begin{array}{c}5 \mathrm{~m} \\
\text { (layer I) }\end{array}$ & $\begin{array}{c}10 \mathrm{~m} \\
\text { (layer II) }\end{array}$ & $\begin{array}{c}20 \mathrm{~m} \\
\text { (layer III) }\end{array}$ & $\begin{array}{c}40 \mathrm{~m} \\
\text { (layer IV) }\end{array}$ \\
\hline Kokonau & $\begin{array}{l}\text { Co } 1, \\
\text { Co } 9\end{array}$ & $\begin{array}{l}\text { Co 2, } \\
\text { Co } 10\end{array}$ & $\begin{array}{l}\text { Co } 3, \\
\text { Co } 11\end{array}$ & $\begin{array}{l}\mathrm{Co} 4, \\
\mathrm{Co} 12\end{array}$ \\
\hline Kamora & K1 & $\mathrm{K} 2$ & K3 & $\mathrm{K} 4$ \\
\hline Tipoeka & T5 & T6 & T7 & T 8 \\
\hline Ajkwa & $\begin{array}{l}\text { A 1, } \\
\text { A } 5\end{array}$ & $\begin{array}{l}\text { A 2, } \\
\text { A } 6\end{array}$ & $\begin{array}{l}\text { A3, } \\
\text { A } 7\end{array}$ & $\begin{array}{l}\text { A 4, } \\
\text { A } 8\end{array}$ \\
\hline Minajerwi & Mi 1 & $\mathrm{Mi} 2$ & Mi 3 & $\mathrm{Mi} 4$ \\
\hline Mawati & Ma 1 & Ma 2 & Ma 3 & $\mathrm{Ma} 4$ \\
\hline Otakwa & $\begin{array}{l}\text { Ot } 5 \text {, } \\
\text { Ot } 13\end{array}$ & $\begin{array}{l}\text { Ot } 6 \text {, } \\
\text { Ot } 14\end{array}$ & $\begin{array}{l}\text { Ot } 7, \\
\text { Ot } 15\end{array}$ & $\begin{array}{l}\text { Ot } 8, \\
\text { Ot } 16\end{array}$ \\
\hline
\end{tabular}

Samples for analyzing benthic community were collected by using a Smith McIntyre grab $\left(0.1 \mathrm{~m}^{2}\right)$ deployed from the winch located on the back platform of the vessel. Sediment samples were taken two times at each station and a small portion of this sample was taken for sediment analyses and copper concentration. The remainder was washed through a $0.5 \mathrm{~m}^{2}$ sieve. The materials

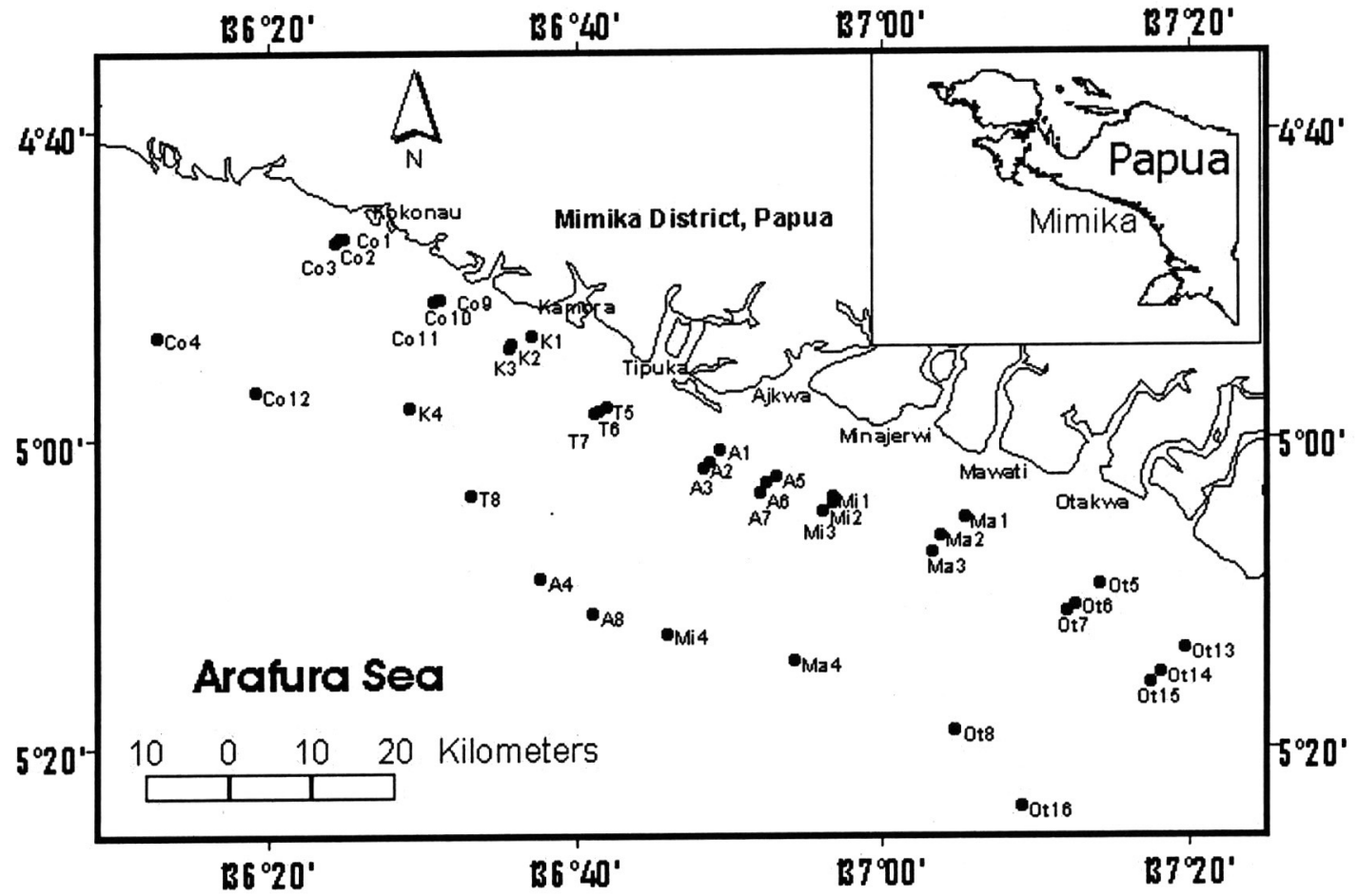

Figure 1. The sampling sites, Mimika district Papua 
remained on the sieve were fixed in $10 \%$ formaldehyde on board the vessel. In the laboratory the animals were removed by visual inspection in illuminated white plastic trays. Animals were transferred to $70 \%$ ethanol and then identified and counted.

Sediment analyses were carried out in Timika Environmental Laboratory (TEL). Measurement of the total copper concentrations was as follows, the sediment was dried under the heat of a flood light, then $0.5 \mathrm{~g}$ of dried sample was digested in a beaker using ultra-pure nitric acid at $80^{\circ} \mathrm{C}$ until almost dry, after that the sample was diluted with $50 \mathrm{ml}$ of DI Water and then analyzed by flame AAS.

Grain size of sediment was analyzed by using Particle Sizer with the range of $0.1 \mu \mathrm{m}-1250 \mu \mathrm{m}$.

\section{Method of Analysis}

Species diversity $\left(\mathrm{H}^{\prime}\right)$ of each station was calculated by Shannon Index, as follows:

$$
H^{\prime}=-\sum_{i=1}^{S} P_{i} \ln P_{i}
$$

Species evenness (E) was calculated by Pielou's index as follows:

$$
E=\frac{H^{\prime}}{\ln S}
$$

Where H' is the index of species diversity, $\mathrm{S}$ is the number of species, and $\mathrm{P}_{i}$ is the proportion of total sample belonging to $;$ th species.

Spearman rank correlation was chosen to test the correlation between physico-chemical variables and benthic community descriptor.

One-way Analysis of variance tests (ANOVA) was used to test for significant differences of diversity and density among the contour depth.

\section{RESULT}

The water depths, number of stations, depth range, particle size and copper concentrations in sediment at each contour depth are listed in Table 1. Sediment textures showed high variation among stations. Very fine sediment (mud) was found at layer II (10 m depth) and layer III (20 m depth). Some coarser sediments sand, sandy mud and muddy sand) were found at the shallow area (layer I) and predominated at the deeper area (layer IV). The mean copper concentrations in sediment ranged $2.5-208.9 \mathrm{mgkg}^{-1}$.

In total, the range of numerical densities at the 40 sampling stations was $195-4,110$ individuals $\mathrm{sm}^{-2}$, with an average of 1,050 individuals $\mathrm{sm}^{-2}$ showing a high density of macrobenthos present at the offshore area of Mimika district. The numerical density at layer I $(5 \mathrm{~m})$ ranged $195-4,110$ with the average of 1,608 ind. $\mathrm{m}^{-2}$ (Fig. 2). The lowest density (195 ind. $\mathrm{m}^{-2}$ ) was found at St. Co9 which was perpendicular to the river Kokonao. Only polychaetes, mollusks and echinoderms could be collected from this station with very low abundances. The highest density $\left(4,110\right.$ ind. $\left.\mathrm{m}^{-2}\right)$ was found at St.Malwhich was perpendicular to the river Mawati. This station was dominated by Owenia sp. (polychaetes) with very high abundance.

At layer II the density ranged between $580-$ 1,630 ind. $\mathrm{m}^{-2}$ with the average of 1,021 ind. $\mathrm{m}^{-2}$ (Fig. 3). The highest density $\left(1,630\right.$ ind. $\left.\mathrm{m}^{-2}\right)$ was found at St. Mi2 which was perpendicular to the Minajerwi river. Two species of polychaetes were dominant namely Cossura sp.2 and Sternaspis sp.1 (Appendix 1).

The density of macrobenthos at layer III and IV ranged 245 - 955 and $345-2,995$ ind. $\mathrm{m}^{-2}$ respectively with the average of 580 and 991 ind. $\mathrm{m}^{-2}$ respectively (Figs. 4 and 5). The highest density at $40 \mathrm{~m}$ depth (layer IV) was found at St.

Table 1. Contour depth (layer of water depth), number of stations, depth range, particle size and copper concentration

\begin{tabular}{|c|c|c|c|c|}
\hline Contour depth & $5 \mathrm{~m}$ (layer I) & $10 \mathrm{~m}$ (layer II) & 20m (layer III) & 40m (layer IV) \\
\hline Number of stations & 10 & 10 & 10 & 10 \\
\hline Depth range & $3.0 \cdot 7.0$ & $8.0-14.0$ & $18.0-23.0$ & $37.0-45.0$ \\
\hline $\begin{array}{r}\text { Median grain size: } \begin{array}{l}\text { mean } \\
\text { range }\end{array} \\
\end{array}$ & $\begin{array}{c}45.2 \\
12.0-123.0 \\
\end{array}$ & $\begin{array}{c}12.2 \\
11.0-15.0 \\
\end{array}$ & $\begin{array}{c}10.0 \\
8.0-13.0 \\
\end{array}$ & $\begin{array}{c}124.9 \\
28.0-171.0 \\
\end{array}$ \\
\hline $\begin{array}{r}\text { Copper concentrations in } \\
\text { sediment }(\mathrm{mg} / \mathrm{kg}) \text { : mean } \\
\text { range }\end{array}$ & $\begin{array}{c}164.4 \\
4.4-936.2 \\
\end{array}$ & $\begin{array}{c}208.9 \\
114.0-490.7 \\
\end{array}$ & $\begin{array}{c}160.3 \\
10.2-354.8 \\
\end{array}$ & $\begin{array}{c}2.5 \\
0.2-5.4 \\
\end{array}$ \\
\hline
\end{tabular}
in sediment. 


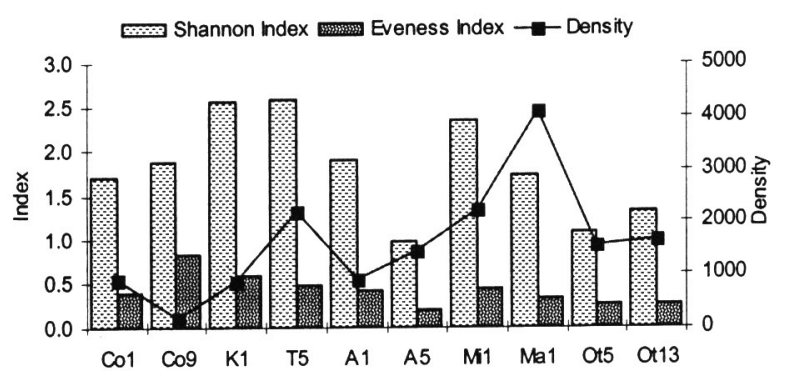

Figure 2. Diversity and evenness indices and density of macrobenthos at layer I

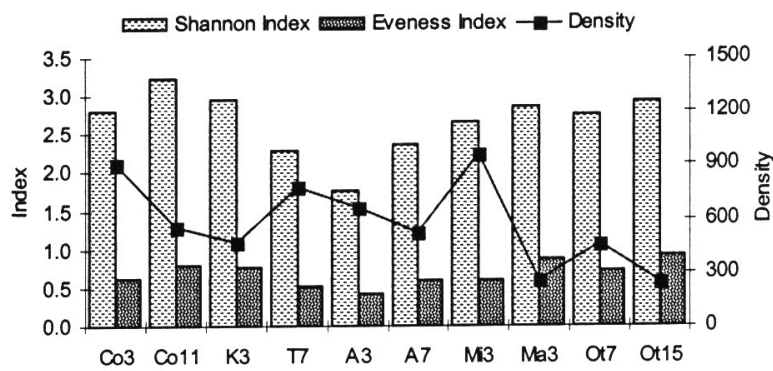

Figure 4. Diversity and evenness indices and density of macrobenthos at layer III.

K4, perpendicular to the river Kamora which was dominated by the polychaetes, Prionospio steenstrupi (Appendix 1). The result of one-way ANOVA test indicated that numerical density showed significantly difference between $5 \mathrm{~m}$ and $20 \mathrm{~m}$ contour depth (Table 2 ). The highest density at $40 \mathrm{~m}$ depth (layer IV) was found at St. K4, perpendicular to the river Kamora which was

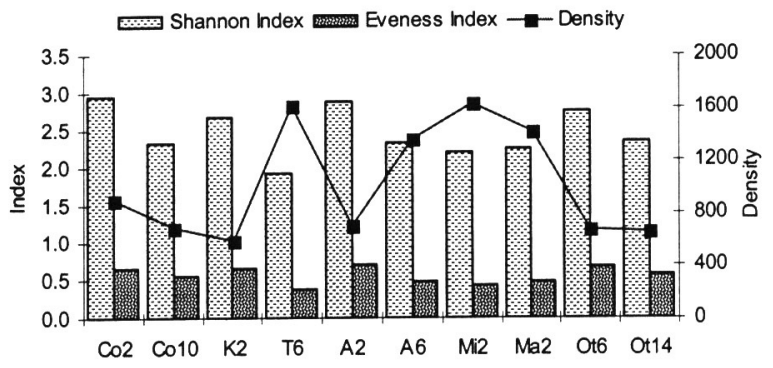

Figure 3. Diversity and evenness indices and density of macrobenthos at layer II

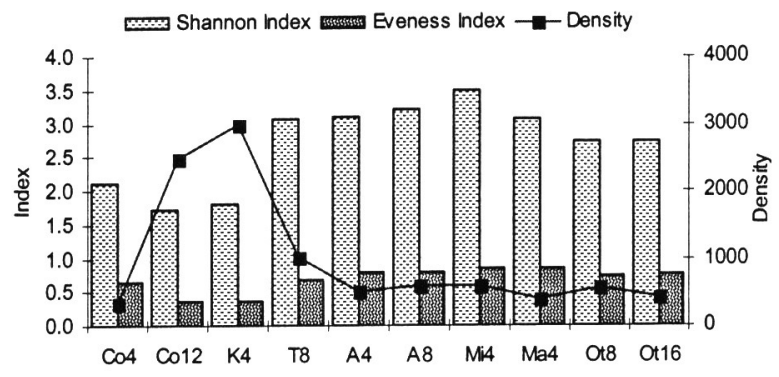

Figure 5. Diversity and evenness indices and density of macrobenthos at layer IV

dominated by the polychaetes, Prionospio steenstrupi.

The diversity indices (H') at layers I, II, III and IV ranged 1.0-2.6, 1.9-2.9, 1.8-3.2 and 1.73.5 respectively with the average of $1.8,2.5,2.7$ and 2.7 respectively (Figs. 2, 3, 4 and 5). The diversity indices tended to increase in deeper water as indicated by one-way ANOVA test (Table 2).

Table 2. One-way ANOVA test

A. Density

Multiple Comparisons

Dependent Variable: SQ DEN

\begin{tabular}{|c|c|c|c|c|c|c|c|}
\hline & \multirow[b]{2}{*}{ (I) DEPTH } & \multirow[b]{2}{*}{ (J) DEPTH } & \multirow{2}{*}{$\begin{array}{c}\text { Mean } \\
\text { Difference } \\
(I-J)\end{array}$} & \multirow[b]{2}{*}{ Std. Error } & \multirow[b]{2}{*}{ Sig. } & \multicolumn{2}{|c|}{$95 \%$ Confidence Interval } \\
\hline & & & & & & Lower Bound & Upper Bound \\
\hline \multirow[t]{12}{*}{$\overline{\mathrm{LSD}}$} & \multirow[t]{3}{*}{5} & 10 & 6.68968 & 4.56762 & .152 & -2.5739 & 15.9533 \\
\hline & & 20 & $14.44790^{*}$ & 4.56762 & .003 & 5.1843 & 23.7115 \\
\hline & & 40 & 8.96639 & 4.56762 & .057 & -.2972 & 18.2300 \\
\hline & \multirow[t]{3}{*}{10} & 5 & -6.68968 & 4.56762 & .152 & -15.9533 & 2.5739 \\
\hline & & 20 & 7.75822 & 4.56762 & .098 & -1.5054 & 17.0218 \\
\hline & & 40 & 2.27671 & 4.56762 & .621 & -6.9869 & 11.5403 \\
\hline & \multirow[t]{3}{*}{20} & 5 & $-14.44790^{*}$ & 4.56762 & .003 & -23.7115 & -5.1843 \\
\hline & & 10 & -7.75822 & 4.56762 & .098 & -17.0218 & 1.5054 \\
\hline & & 40 & -5.48151 & 4.56762 & .238 & -14.7451 & 3.7821 \\
\hline & \multirow[t]{3}{*}{40} & 5 & -8.96639 & 4.56762 & .057 & -18.2300 & .2972 \\
\hline & & 10 & -2.27671 & 4.56762 & .621 & -11.5403 & 6.9869 \\
\hline & & 20 & 5.48151 & 4.56762 & .238 & -3.7821 & 14.7451 \\
\hline
\end{tabular}

*. The mean difference is significant at the .05 level. 


\section{B. Species diversity}

\section{Multiple Comparisons}

Dependent Variable: DIVERSITY

\begin{tabular}{|c|c|c|c|c|c|c|}
\hline \multirow[b]{2}{*}{ (I) DEPTH } & \multirow[b]{2}{*}{ (J) DEPTH } & \multirow{2}{*}{$\begin{array}{c}\text { Mean } \\
\text { Difference } \\
(I-J)\end{array}$} & \multirow[b]{2}{*}{ Std. Error } & \multirow[b]{2}{*}{ Sig. } & \multicolumn{2}{|c|}{ 95\% Confidence Interval } \\
\hline & & & & & Lower Bound & Upper Bound \\
\hline \multirow[t]{3}{*}{5} & 10 & $-.65700^{*}$ & .22369 & .006 & -1.1107 & -.2033 \\
\hline & 20 & $-.85000^{*}$ & .22369 & .001 & -1.3037 & -.3963 \\
\hline & 40 & $-.89800^{*}$ & .22369 & .000 & -1.3517 & -.4443 \\
\hline \multirow[t]{3}{*}{10} & 5 & $.65700^{*}$ & .22369 & .006 & .2033 & 1.1107 \\
\hline & 20 & -.19300 & .22369 & .394 & -.6467 & .2607 \\
\hline & 40 & -.24100 & .22369 & .288 & -.6947 & .2127 \\
\hline \multirow[t]{3}{*}{20} & 5 & $.85000^{*}$ & .22369 & .001 & .3963 & 1.3037 \\
\hline & 10 & .19300 & .22369 & .394 & -.2607 & .6467 \\
\hline & 40 & -.04800 & .22369 & .831 & -.5017 & .4057 \\
\hline \multirow[t]{3}{*}{40} & 5 & $.89800^{*}$ & .22369 & .000 & .4443 & 1.3517 \\
\hline & 10 & .24100 & .22369 & .288 & -.2127 & .6947 \\
\hline & 20 & .04800 & .22369 & .831 & -.4057 & .5017 \\
\hline
\end{tabular}

${ }^{*}$. The mean difference is significant at the .05 level.

The evenness indices (even individuals distributions among species) were not high (Figs 2, 3, 4 and 5) with the highest average of 0.68 and 0.69 (Figs 2 and 5). This indicated that many dominant species existed in the study areas.

In total 266 species of macrobenthos were collected from the study area (Appendix 1) and polychaetes was the dominant group accounted for $51.33 \%$ followed by the crustaceans $(20.35 \%)$, mollusks (10.62\%) and echinoderms (3.98\%). The miscellaneous group included brachiopods, chordates, cnidarians, nemerteans, sipunculids and unidentified species accounted for $17.69 \%$ (Table 3).

Table 3. Percent composition of major taxa of macrobenthos from the study area 2005.

\begin{tabular}{|l|c|}
\hline \multicolumn{1}{|c|}{ Major taxa } & $\%$ \\
\hline Polychaeta & 51.33 \\
\hline Crustacea & 20.35 \\
\hline Mollusca & 10.62 \\
\hline Echinodermata & 3.98 \\
\hline Miscellaneous group & 17.69 \\
\hline
\end{tabular}

Based on the high abundance, layer I was dominated by polychaetes (Owenia sp.), crustaceans (Ampelisca sp. and Eriopisa sp.) and sipunculid (Apionsoma sp.). Polychaetes (Sternaspis sp. and Cossura sp.), crustaceans
(Ampelisca sp.) and sipunculids (Apionsoma sp.) dominated layer II. Layer III was dominated by polychaetes (Sternaspis sp., Cossura sp, and Poechilochaetus sp,) and crustaceans (Eriopisa sp. and Idunella sp.) and layer IV was dominated by polychaetes (Paraprionospio steenstrupi and Paraprionospio malmgreni), crustaceans (Ostracoda, Ampelisca sp. and Apseudes sp.) and sipunculids (Apionsoma sp.) (Appendix 1).

The correlation between physico-chemical parameters and bethic community structure is listed in Table 4. There was positive correlation between median grain size of sediment particle and water depth. The bottom sediment of shallower layers consisted of silt-clay fraction and the deeper layer had coarser sediment (Fig. 6).

Figure 7 shows the composition of dominant group of taxa based on the high abundance. Polychaeta belong to the phylum Annelida was the dominant group at each layer of water depth ranging from $50 \%$ to $80 \%$. The second dominant taxa was small crustaceans which was included in the phylum Arthropoda. Nemertea and miscellaneous group comprised of lesser taxa (sipunculids, echiurids, anthozoans, ascideans, chordates, etc.) were poorly represented. 
Table 4. Spearman rank correlation coefficient between physico-chemical variable and benthic community descriptor.

\begin{tabular}{|l|l|l|l|l|l|l|}
\hline & Depth $(\mathbf{m})$ & $\begin{array}{c}\text { Diversity } \\
\text { index }\left(\mathrm{H}^{\prime}\right)\end{array}$ & $\begin{array}{c}\text { Evennes } \\
\text { index (E) }\end{array}$ & $\begin{array}{c}\text { Density } \\
(\text { ind./m²) }\end{array}$ & $\begin{array}{c}\text { Cu } \\
(\mathrm{mg} / \mathrm{kg})\end{array}$ & $\begin{array}{c}\text { Med. Grain } \\
\text { size }(\boldsymbol{\mu})\end{array}$ \\
\hline Depth & 1.00 & & & & & \\
\hline $\mathrm{H}^{\prime}$ & 0.47 & 1.00 & & & & \\
\hline $\mathrm{E}$ & 0.43 & 0.86 & 1.00 & & & \\
\hline Density & -0.21 & -0.50 & -0.71 & 1.00 & & \\
\hline $\mathrm{Cu}$ & -9.38 & -0.20 & -0.27 & 0.03 & 1.00 & \\
\hline $\begin{array}{l}\text { Med. } \\
\text { grain size }\end{array}$ & 0.67 & 0.09 & 0.08 & 0.07 & -0.43 & 1.00 \\
\hline
\end{tabular}

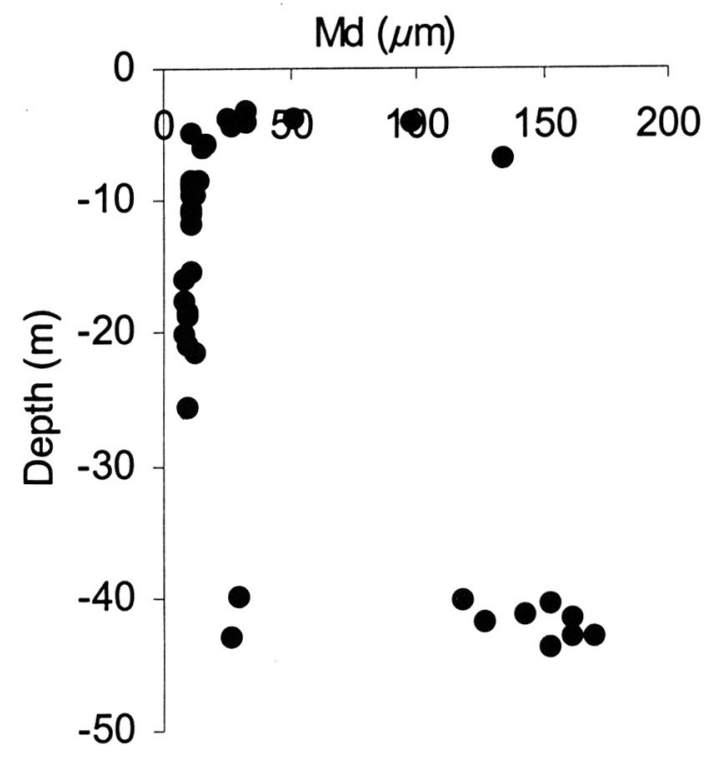

Figure 6. Correlation between median grain size and water depth

$(\mathrm{Md}=$ median gran size $)$

Dominant family of macrobenthos at each layer of water depth is illustrated in Figure 8. Layer I (5 $m$ depth) was dominated by Owenidae, Capitellidae, Sternaspidae, Cossuridae and

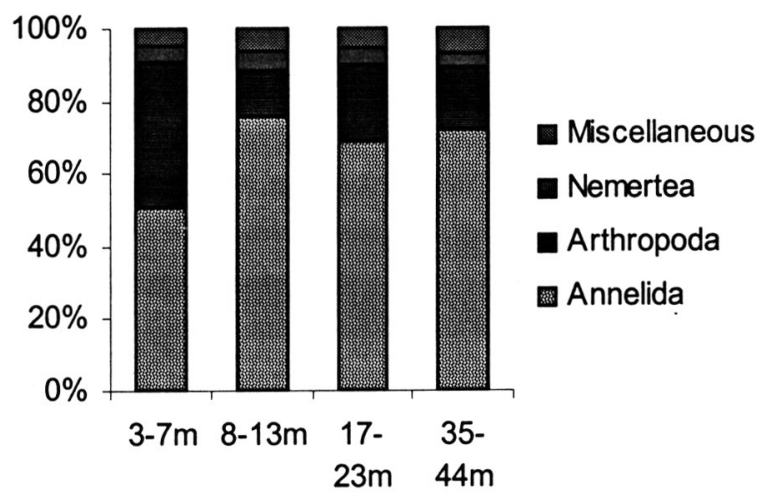

Figure 7. Taxa composition of macrobenthos of layer III and 35-44m: layer IV. 3-7m: layer I, 8-13m: layer II, $17-23 \mathrm{~m}:$
Spionidae (Polychaeta), Gammaridae and Ampeliscidae (Crustacea) with Owenidae, Gammaridae and Ampeliscidae were the prominent families. Families Spionidae, Cossuridae and Sternaspidae were the prominent families of layer II. At layer III and IV, families Sternaspidae, Spionidae and Gammaridae were the prominent ones.

\section{DISCUSSION}

The overall average of macrobenthic density of the study area was 1050 ind. $\mathrm{m}^{-2}$ showing a high density of the offshore area of Mimika district. Kastoro (1992) found the average densities of macrobenthos from Banten Bay (West Java, Indonesia) and the offshore area of Jakarta Bay (Jakarta, Indonesia) were 840.70 and 370.20 ind $\mathrm{m}^{-2}$ respectively. Chatananthawej and Bussarawit (1987) studied the macro-benthic fauna along the west coast of Thailand in the Andaman Sea found the overall average density of macrobenthos was 889 ind. $\mathrm{m}^{-2}$. The average density of $386.60 \mathrm{ind} . / \mathrm{m}^{2}$ was found in the offshore of Tukang coast, southwest Taiwan which showed

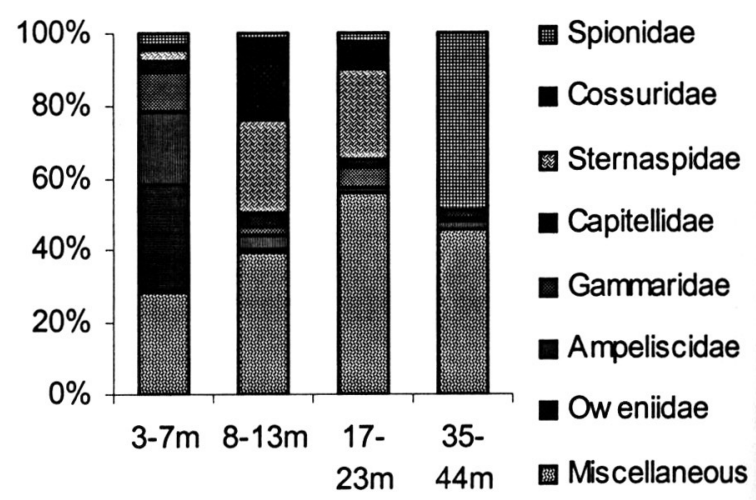

Figure 8. Dominant family of macrobenthos of study area 2005. 
a low production in shallow waters facing to the open sea (Kuwabara and Akimoto, 1986). High density of macrobenthos of the study area might be due to the nutrient load discharged into this area.

Rivers in Mimika district are surrounded by dense mangrove forests. Mangrove root, branch and leaf litters are decomposed by bacteria on the bottom resulting detritus production which was spread out to the estuaries due to the tidal activities. Estuaries as a class of habitats rank along with tropical rain forest are naturally productive ecosystems (Odum, 1971). The water containing the organic matter will be flushed down to the ocean caused by the continuous flow of fresh water from the river to the estuary and mixed with sea water. Most of them will be flushed down to the ocean to compensate for the next coming fresh water and a small amount will be evaporated (Nijbakken, 1986).

The density of macrobenthos of the study area tended to decrease in deeper water. The abundance of macrobenthic fauna declines with depth is a phenomenon which has been found in many other regions of the sea (Seidefaden et al., 1968; Ansari et al., 1977). The density of benthos in the soft sediment decreased with the increasing depth $(6000$ ind. $/ \mathrm{m}^{2}$ on continental shelf down to $25-100$ ind. $\mathrm{m}^{-2}$ on the abyssal plain), as might be expected because of declining productivity with depth (Sanders and Hessler, 1969).

The diversity of macrobenthos of present study tended to increase in deeper water. Kastoro (1992) found the diversity index $\left(\mathrm{H}^{\prime}\right)$ were higher in the offshore area of Jakarta Bay compared with those in the estuarine area of Jakarta Bay. Kobawara and Akimoto (1986) also found the diversity index of macrobenthos of the offshore area of Tukang, southwest Taiwan were higher in deeper stations compared with those in shallow stations. Other workers have suggested that benthic macroinvertebrate diversity increases from shallow areas to deep sea (Sanders, 1968; Grassle and Maciolek, 1992). Besides, the bottom sediment of the deeper layer of the present study is coarser than those in shallower layer consisting of fine sand, sandy mud and muddy sand.

This various types of sediment provide habitats for greater diversity of benthic species to settle down. The present study recorded that polychaetes was the major component of macrobenthos based on the density and number of species. Polychaetes occur in almost all benthic marine and estuarine sediments (Fauchald, 1977). They are often the dominant component of macrobenthos both in terms of number of species and individuals (Grassle and Maciolek, 1992). Many factors influence the distribution and abundance of polychaetes, including sediment structure, organic content, depth, salinity and temperature. Polychaete densities are lower in exposed sandy beaches and in coarser sub-tidal sediments than in finer sediments (Knox, 1977 in Hutchings, 1998). Since the bottom sediment of the study area dominated by fine sediment, polychaetes were the dominant group.

\section{CONCLUSION}

Based on the density, macrobenthos of the study area show relatively high production. In total 266 species of macrobenthos collected from the study area show relative high diversity if it is compared with the other areas of Indonesian waters, such as Banten Bay (121 species) and offshore area of Jakarta Bay (155 species) (Kastoro, 1992) and Java Sea (373 species) (De Wilde et al., 1989).

Density of macrobenthos tends to decrease in deeper water and diversity tends to increase. Among the macrobenthos, polychaete is the dominant group $(50-80 \%)$.

The Ajkwa estuary in particular receives not only natural sediment but also some fraction of tailings resulting high rates of sedimentation. New islands are forming throughout the estuary, and the estuary itself is moving further out into the sea. It is assumed that high rates of sedimentation will have the deleterious effects on macrobenthic communities of the offshore area of Ajkwa estuary. According to the results of present study, the diversity index $\left(\mathrm{H}^{\prime}\right)$ of $\mathrm{St}$. A1 located at layer I (5m depth) which is perpendicular to the Ajkwa river mouth is higher than those at stations Ot5 which is perpendicular to the Otakwa river mouth (control estuary) (Fig.2). It seems the high rates of sedimentation of Ajkwa estuary and copper concentrations in sediment did not influence the macrobenthic communities of the off shore area.

Acknowledgement. We are grateful to the team of Manager of PT Freeport-Indonesia for giving us the opportunity to present the macrobenthic data of this company and reviewing this manuscript. We also thank the technicians of PT Freeport- 
Indonesia and Research Center for Oceanography, Indonesian Institute of Sciences for helping us in processing the data.

\section{REFERENCES}

Ansari, Z.A., S.N. Harkantra, S.A. Nain and A.H. Parulekar. 1977. Benthos of the Bay of Bengal: A preliminary account. Mahasagar, $10(1 \& 2): 55-$ 60.

Bilyard, G.R. 1987. The value of benthic infauna in marine pollution monitoring studies. Marine Pollution Bulletin 18: 581-585.

Collison, G.H.P.E. and W.F.P.E. Brumund. 1997. Conceptual tailings option study. PT FreeportIndonesia - Golder Associates Georgia USA.

Chatananthawej, B. and S. Bussarawit. 1987. Quantitative survey of the macrobenthos fauna along the west coast of Thailand in the Andaman Sea. Res. Bull. 47: 1-23.

De Wilde, P.A.W., W.W. Kastoro, E.M. Burguis, I. Aswandy, I.A. Hakim and A. Kock. 1989. Structure and energy demand of the benthic soft bottom communities in Java Sea and around the islands of Madura and Bali. Nether. J. S. Res. 23 (4): 449-461.

Fauchald, K. 1977. The polychaete worms, definitions and keys to the orders, families and genera. Nat. Hist. Mus. LA Country Mus. Sci. Ser. 28: 1-190.

Grassle, J.F. and N.J., Maciolek. 1992. Deep sea species richness: regional and local diversity estimates from quantitative bottom sampling. Am. Nat. 139: 313-341.
Heip C. and J.A. Craeymeersch. 1995. Benthic community structures in the North Sea. Helgolander Meeresuntersuhungen 49: 313-328.

Hutchings, P. 1998. Biodiversity and functioning of polychaetes in benthic sediments. Biodiversity and Conservation 7: 1133-1145.

Kastoro, W.W. 1992. Marine soft bottom benthic communities in coastal areas of Indonesia. Third ASEAN Science and Technology Conference Proceedings Volume 6: Marine Science: Living Coastal Resources (Chou Lok Ming and Clive R. Wilkinson eds.) 21-23 September 1992 Singapore: 185-192. ASEAN-Australia Cooperative Program in Marine Science.

Kuwabara, R. and Y. Akimoto. 1986. The offshore environment of Tukang, Southwest Taiwan. II. Macro-benthos. Proceedings of the first Asian Fisheris Forum, Manila, Philippines 26-31 May 1986 (Maclean, Dizon and Hosillos eds.): 193-198. The Asian Fisheries Society Manila, Philippines.

Nijbakken, J.W. 1982. Biologi laut suatu pendekatan ekologis: 458 pp. Gramedia Jakarta, 1988.

Odum, E.P. 1971. Fundamentals of ecology Third edition: 574 pp. W.B. Saunders Company, Toppan Company, Ltd. Tokyo, Japan.

Sanders, H.L. 1968. Marine benthic diversity: a comparative study. Am. Nat. 102: 243-281.

Sanders, H.L. and R.R. Hessler. 1969. Ecology of the deep sea benthos. Science 163: 1419-1424.

Seidenfaden, G., T. Smittinand and G. Thorson. 1968. Report on the fifth Thai-Danish Expedition 1966. Nat. Hist. Bull. Siam Soc. 22: 245-261. 
Appendix I. List of species of macrobenthos (two grab samples) at each layer of water depth (contour depth) 2005

\begin{tabular}{|c|c|c|c|c|c|c|}
\hline No. & Species & Family/Order & Layer I & Layer II & Layer III & Layer IV \\
\hline & Annelida/Polychaeta & & & & & \\
\hline 1 & Acoetes sp. & Acoetidae & 1 & - & - & - \\
\hline 2 & Aglaophamus sp. & Nephtyidae & 1 & 9 & 1 & 6 \\
\hline 3 & Amphicteis sp. & Ampharetidae & 1 & 2 & - & - \\
\hline 4 & Aricidea sp. & Paraonidae & 1 & - & 1 & 4 \\
\hline 5 & Ancistrosyllis sp. & Pilargidae & - & 9 & 8 & - \\
\hline 6 & Ampharete sp. & Ampharetidae & - & 4 & 9 & 3 \\
\hline 7 & Aonides sp. & Spionidae & $\cdot$ & 4 & 2 & 15 \\
\hline 8 & Axiothella sp. & Maldanidae & - & 2 & 2 & 6 \\
\hline 9 & Boccardia sp. & Spionidae & - & - & - & 2 \\
\hline 10 & Cabira sp. & Pilargidae & 1 & 8 & 2 & 1 \\
\hline 11 & Chloeia sp. & Amphinomidae & 10 & - & 2 & - \\
\hline 12 & Chloeia violacea & Amphinomidae & 5 & 6 & - & 1 \\
\hline 13 & Chone sp. & Sabellidae & - & - & - & 5 \\
\hline 14 & Chaetopterus sp. & Chaetopteridae & $\cdot$ & - & - & 2 \\
\hline 15 & Cirratulus sp. & Cirratulidae & 12 & 25 & 7 & 2 \\
\hline 16 & Cirratulus sp. & Cirratulidae & 1 & 4 & - & - \\
\hline 17 & Cirratulus sp. & Cirratulidae & 4 & 6 & - & - \\
\hline 18 & Cossura sp. & Cossuridae & 9 & 15 & 1 & 2 \\
\hline 19 & Cossura sp.1 & Cossuridae & 36 & 230 & 64 & 1 \\
\hline 20 & Cossura sp.2 & Cossuridae & 5 & 208 & 52 & 3 \\
\hline 21 & Cossura sp. 3 & Cossuridae & $\cdot$ & - & 49 & 3 \\
\hline 22 & Clymenella sp. & Maldanidae & 1 & 1 & 1 & 5 \\
\hline 23 & Diopatra sp. & Onuphidae & 5 & 3 & 6 & 1 \\
\hline 24 & Epidiopatra sp. & Onuphidae & 1 & - & - & $\cdot$ \\
\hline 25 & Eunice sp. & Eunicidae & - & - & - & 9 \\
\hline 26 & Eunice sp.1 & Eunicidae & - & 3 & - & 5 \\
\hline 27 & Eunice sp.2 & Eunicidae & - & - & $\cdot$ & 2 \\
\hline 28 & Eunice sp.2 & Eunicidae & - & - & - & 2 \\
\hline 29 & Euclymene sp. & Maldanidae & - & - & 1 & 9 \\
\hline 30 & Euniphysa sp. & Euniphysidae & - & - & 2 & 2 \\
\hline 31 & Exogone sp. & Syllidae & 28 & 1 & - & 4 \\
\hline 32 & Flabelligera sp. & Flabelligeridae & - & 4 & 3 & - \\
\hline 33 & Flabelligera sp.1 & Flabelligeridae & - & $\cdot$ & - & 1 \\
\hline 34 & Flabelligera sp.2 & Flabelligeridae & - & - & - & 1 \\
\hline 35 & Glycinde sp. & Goniadidae & 27 & 11 & 2 & 7 \\
\hline 36 & Glycera sp. & Glyceridae & - & 6 & - & 5 \\
\hline 37 & Glycera sp. 1 & Glyceridae & 14 & 15 & 16 & 17 \\
\hline 38 & Glycera sp.2 & Glyceridae & 6 & 4 & 3 & 12 \\
\hline 39 & Lycera sp. 3 & Glyceridae & - & - & 1 & - \\
\hline 40 & Goniada sp. & Goniadidae & 27 & 11 & 2 & 7 \\
\hline 41 & Goniada sp.1 & Goniadidae & 8 & - & 5 & $\cdot$ \\
\hline 42 & Goniada sp.2 & Goniadidae & 6 & - & 2 & - \\
\hline 43 & Gyptis sp. & Hesionidae & 1 & 4 & 2 & 2 \\
\hline 44 & Hesione sp. & Hesionidae & 5 & 15 & 7 & 4 \\
\hline 45 & Heteromastus sp. & Capitellidae & 34 & 30 & 2 & 28 \\
\hline 46 & Hyalonoechia sp. & Onuphidae & - & - & - & 2 \\
\hline 47 & Isolda sp. & Ampharetidae & - & - & 5 & 3 \\
\hline 48 & Laonice sp. & Spionidae & 1 & - & - & - \\
\hline 49 & Lianira sp. & Sigalionidae & - & $\cdot$ & 2 & - \\
\hline 50 & Laetmonice sp. & Aphroditidae & - & - & 1 & - \\
\hline 51 & Leonates sp. & Nereidae & 6 & 1 & - & 4 \\
\hline 52 & Lumbrineris sp. & Lumbrineridae & 1 & - & - & 1 \\
\hline
\end{tabular}


Appendix 1. (continued)

\begin{tabular}{|c|c|c|c|c|c|c|}
\hline No. & Specles & Family/Order & Layer I & Layer II & Layer III & Layer IV \\
\hline 53 & Lumbrineris sp.1 & Lumbrineridae & 1 & 9 & $\cdot$ & 1 \\
\hline 54 & Lumbrineris sp.2 & Lumbrineridae & $\cdot$ & 7 & 1 & 7 \\
\hline 55 & Lumbrineris sp. 3 & Lumbrineridae & 2 & $\cdot$ & 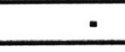 & $\cdot$ \\
\hline 56 & Lumbrineris sp.4 & Lumbrineridae & $\cdot$ & $\cdot$ & $\dot{-}$ & 2 \\
\hline 57 & Levinsenia sp. & Paraonidae & - & - & 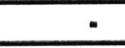 & 2 \\
\hline 58 & Lepidonotus Sp. & Polynoidae & 1 & 13 & 3 & 1 \\
\hline 59 & Lumbrinerides sp. & Lumbrineridae & 22 & 4 & 21 & 2 \\
\hline 60 & Lumbrinerides sp. 1 & Lumbrineridae & 2 & $\cdot$ & $\div$ & $\cdot$ \\
\hline 61 & Lumbrinerides sp.2 & Lumbrineridae & 4 & $\dot{-}$ & $\dot{-}$ &. \\
\hline 62 & Lepidasthenia sp. & Polynoldae & 2 & 10 & 5 & - \\
\hline 63 & Magelona sp. & Magelonidae & $\cdot$ & 6 & 1 & 9 \\
\hline 64 & Magelona sp.1 & Magelonldae & 30 & 40 & 11 & 17 \\
\hline 65 & Magelona sp.2 & Magelonidae & 20 & 23 & 17 & 11 \\
\hline 66 & Magelona sp. 3 & Magelonidae & 8 & 9 & $\cdot$ & 2 \\
\hline 67 & Maldane sp. & Maldanidae & 10 & - & 7 & 9 \\
\hline 68 & Malmgreniella sp. & Polynoidae & $\cdot$ & 5 & 3 & 3 \\
\hline 69 & Mediomastus sp. & Capitellidae & 18 & 12 & 6 & 2 \\
\hline 70 & Mellina sp. & Ampharetidae & 5 & 11 & 16 & 8 \\
\hline 71 & Minuspio sp. & Splonidae & 7 & 3 & $\cdot$ & 19 \\
\hline 72 & Myriochelle sp. & Owenidae & $\cdot$ & 6 & - & $\cdot$ \\
\hline 73 & Nephtys sp. & Nephtyidae & $\cdot$ & 4 & 3 & 21 \\
\hline 74 & Nephtys sp.1 & Nephtyidae & 21 & 33 & 31 & 24 \\
\hline 75 & Nephtys sp.2 & Nephtyidae & 10 & 21 & 18 & 1 \\
\hline 76 & Nephtys sp.3 & Nephtyidae & $\cdot$ & 5 & 7 & 1 \\
\hline 77 & Nematonereis unicornis & Nereidae & $\dot{-}$ & $\cdot$ & $\cdot$ & 6 \\
\hline 78 & Nerinides sp. & Nereidae & 21 & 1 & 1 & 19 \\
\hline 79 & Notomastus sp. & Capitellidae & 49 & 41 & 15 & 16 \\
\hline 80 & Onuphis sp. & Onuphidae & 2 & $\cdot$ & $\cdot$ & $\cdot$ \\
\hline 81 & Ophiodromus sp. & Hesionidae & 2 & - & $\cdot$ & $\cdot$ \\
\hline 82 & Ophelia sp. & Opheliidae & $\overline{-}$ & 1 & 1 & $\cdot$ \\
\hline 83 & Opistrosyllis sp. & Syllidae & $\cdot$ & $\cdot$ & $\cdot$ & 2 \\
\hline 84 & Owenia sp. & Owenidae & 927 & - & - & $\ddot{-}$ \\
\hline 85 & Parandalia sp. & Pillargidae & $\cdot$ & 4 & 10 & $\cdot$ \\
\hline 86 & Parandalia sp.1 & Pillargidae & $\cdot$ & 1 & 2 & 5 \\
\hline 87 & Parandalia sp.2 & Pilargidae & $\cdot$ & - & 1 & 3 \\
\hline 88 & Paraonis sp. & Paraonidae & $\cdot$ & - & 1 & 5 \\
\hline 89 & Paranaitis sp. & Phyllodocidae & 2 & - & - & 2 \\
\hline 90 & Paralacydonia sp. & Lacydonidae & 8 & 6 & 1 & 30 \\
\hline 91 & Perinereis sp. & Nereidae & 2 & - & $\cdot$ & 2 \\
\hline 92 & Pectinaria sp. & Pectinarilidae & 2 & - & - & $\cdot$ \\
\hline 93 & Pista unibranchiata & Terebellidae & $\cdot$ & 3 & $\cdot$ & $\cdot$ \\
\hline 94 & Pista sp. & Terebellidae & $\cdot$ & 1 & 6 & $\cdot$ \\
\hline 95 & Phyllodoce sp. & Phyllodocidae & 1 & - & $\cdot$ & 15 \\
\hline 96 & Platynereis sp. & Nereidae & 1 & - & - & 4 \\
\hline 97 & Poechilochaetus sp. & Poechilochaetidae & - & 1 & 33 & 3 \\
\hline 98 & Polycirrus sp. & Terebellidae & $\cdot$ & 1 & 6 & 3 \\
\hline 99 & Polydora sp. & Spionidae & 4 & - & $\cdot$ & - \\
\hline 100 & Prionospio sp. & Spionidae & - & - & 2 & $\cdot$ \\
\hline 101 & Prionospio ehlersi & Spionidae & 9 & 6 & 2 & 12 \\
\hline 102 & Prionospio libata & Spionidae & $\cdot$ & 2 & 1 & - \\
\hline 103 & Prionospio lighti & Spionidae & $\cdot$ & 3 & - & - \\
\hline 104 & Prionospio malmgreni & Spionidae & 16 & 1 & 3 & 59 \\
\hline 105 & Prionospio pinnata & Spionidae & 1052 & 35 & 19 & 3 \\
\hline 106 & Prionospio steenstrupi & Splonidae & 48 & 20 & 12 & 831 \\
\hline 107 & Pulliella sp. & Capitellidae & 16 & - & $\cdot$ & $\cdot$ \\
\hline
\end{tabular}


Appendix 1. (continued)

\begin{tabular}{|c|c|c|c|c|c|c|}
\hline No. & Species & Family/Order & Layer I & Layer II & Layer III & Layer IV \\
\hline 108 & Scalibregma sp. & Scalibregmidae & 2 & 2 & 1 & 18 \\
\hline 109 & Scoloplos sp. & Orbiniidae & 1 & - & 2 & 1 \\
\hline 110 & Scololepis sp. & Spionidae & - & - & - & 1 \\
\hline 111 & Sigalion sp. & Sigalionidae & 1 & 3 & 1 & 4 \\
\hline 112 & Sigambra sp. & Pilargidae & 1 & 8 & 4 & 2 \\
\hline 113 & Sigambra sp.1 & Pilargidae & 4 & 18 & 28 & 3 \\
\hline 114 & Sigambra sp.2 & Pilargidae & 3 & 19 & 9 & 2 \\
\hline 115 & Spiophanes sp. & Spionidae & 1 & 1 & 1 & 3 \\
\hline 116 & Spiochaetopterus sp. & Chaetopteridae & - & 1 & - & - \\
\hline 117 & Stenelais sp. & Aphrodiidae & 2 & - & 3 & - \\
\hline 118 & Stenelais sp.1 & Aphroditidae & - & 8 & - & - \\
\hline 119 & Sternaspis sp.1 & Sternaspidae & 68 & 415 & 163 & 4 \\
\hline 120 & Sternaspis sp.2 & Sternaspidae & 21 & 106 & 121 & 4 \\
\hline 121 & Stylaroides sp. & Flabelligeridae & - & 4 & 9 & 10 \\
\hline 122 & Synelmis sp. & $\begin{array}{l}\text { Pilargidae } \\
\end{array}$ & - & 2 & - & 1 \\
\hline 123 & Terebellides sp. & Terebellidae & 1 & - & - & - \\
\hline 124 & Terebellides stroemi & Terebellidae & - & 2 & 2 & 8 \\
\hline 125 & Trochochaeta sp. & Trochochaetidae & - & $\cdot$ & 1 & - \\
\hline & Arthropoda/Crustacea & & & & & \\
\hline 126 & Acetes sp. & Sergestidae & - & - & 1 & 1 \\
\hline 127 & Alpheus sp. & Alpheidae & - & 5 & 17 & - \\
\hline 128 & Ampelisca sp. & Ampeliscidae & 645 & 54 & 19 & 41 \\
\hline 129 & Anchysquilla sp. & Squillidae & 5 & 2 & - & - \\
\hline 130 & Apseudes sp. & Apseudidae & 17 & 5 & 4 & 38 \\
\hline 131 & Atylus sp. & Atylidae & - & - & 11 & 4 \\
\hline 132 & Byblis sp. & Ampeliscidae & - & 6 & 4 & 13 \\
\hline 133 & Caprella sp. & Caprellidae & 9 & - & - & - \\
\hline 134 & Callianassa sp. & Callianassidae & - & 9 & 22 & 3 \\
\hline 135 & Carcinoplax sp. & Goneplacidae & - & 1 & 1 & - \\
\hline 136 & Cerapus sp. & Corophidae & 22 & 3 & - & 4 \\
\hline 137 & Charybdis sp. & Portunidae & - & - & - & 1 \\
\hline 138 & Cirolana sp. & Cirolanidae & 4 & 3 & 13 & 1 \\
\hline 139 & Clorida sp. & Squillidae & 1 & 15 & 3 & 1 \\
\hline 140 & Colurostylis sp. & Bodotriidae & - & 6 & 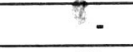 & 1 \\
\hline 141 & Cyclaspis sp. & Bodotriidae & 30 & 18 & 80 & 19 \\
\hline 142 & Cyathura sp. & Anthuridae & 19 & - & - & 16 \\
\hline 143 & Diogenes sp. & Diogenidae & 5 & - & - & 13 \\
\hline 144 & Ericthonius sp. & Corophidae & 1 & - & 1 & - \\
\hline 145 & Grandidierella sp. & Aoridae & 14 & 1 & - & 2 \\
\hline 146 & Eriopisa sp. & Gammaridae & 340 & 48 & 60 & 5 \\
\hline 147 & Gammaropsis sp. & Isaeidae & 2 & - & - & - \\
\hline 148 & Gnathia sp. & Gnathiidae & - & - & - & 1 \\
\hline 149 & Idotea sp. & Idoteiidae & 2 & - & - & - \\
\hline 150 & Idunella sp. & Liljeborgidae & 11 & 12 & 33 & - \\
\hline 151 & Jassa sp. & Ischyroceridae & $\cdot$ & - & 11 & - \\
\hline 152 & Leptochelia sp. & Anthuridae & - & 1 & - & 12 \\
\hline 153 & Leucothoe sp. & Leucothoidae & - & 2 & 2 & 1 \\
\hline 154 & Leucosia sp. & Leucosiidae & - & - & - & 2 \\
\hline 155 & Malacanthura sp. & Anthuridae & 1 & - & - & - \\
\hline 156 & Macrophthalmus sp. & Ocypodidae & - & - & $=$ & 2 \\
\hline 157 & Monoculodes sp. & Oedicerotidae & 4 & 2 & 2 & 1 \\
\hline 158 & Munida sp. & Galatheidae & - & - & $3-$ & 1 \\
\hline 159 & Mysis sp. & Mysidae & 4 & - & 4 & 1 \\
\hline 160 & Neasticilla sp. & Arcturidae & $\cdot$ & - & - & 1 \\
\hline 161 & Neodorippe sp. & Dorippidae & 1 & - & - & - \\
\hline
\end{tabular}


Appendix 1. (continued)

\begin{tabular}{|c|c|c|c|c|c|c|}
\hline No. & Species & Family/Order & Layer I & Layer II & Layer III & Layer IV \\
\hline 162 & Ogyrides sp. & Ogyriidae & 12 & - & 4 & 3 \\
\hline 163 & Ostracoda & Ostracoda & 43 & 1 & 1 & 111 \\
\hline 164 & Paraphoxus sp. & Phoxocephallidae & - & - & - & 8 \\
\hline 165 & Palaemon sp. & Palaemonidae & 1 & 1 & 2 & - \\
\hline 166 & Periclimenes sp. & Palaemonidae & - & - & 1 & - \\
\hline 167 & Photis sp. & Isaeidae & 78 & 6 & 17 & 13 \\
\hline 168 & Pinnixa sp. & Pinnotheridae & 1 & $\cdot$ & - & - \\
\hline 169 & Pontonides sp. & \begin{tabular}{|l} 
Ogyriidae \\
\end{tabular} & 3 & 3 & 5 & 7 \\
\hline 170 & Portunus sp. & \begin{tabular}{|l|} 
Portunidae \\
\end{tabular} & 1 & $\cdot$ & 1 & 2 \\
\hline 171 & Pycnogonum sp. & Pycnogonidae & - & - & - & 1 \\
\hline 172 & Randalia sp. & Leucosiidae & 1 & - & - & - \\
\hline 173 & Stathmos sp. & Sphaeromatidae & 1 & - & - & 5 \\
\hline 174 & Tanais sp. & \begin{tabular}{|l|} 
Tanaidae \\
\end{tabular} & 1 & - & - & 5 \\
\hline 175 & Typhlocaricinus sp. & Goneplacidae & - & 2 & 16 & 5 \\
\hline 176 & Upogebia sp. & Upogebiidae & 1 & 3 & 18 & 20 \\
\hline 177 & Urothoe sp. & Hautoriidae & 10 & - & - & 1 \\
\hline 178 & Xenophthalmus sp. & Xanthidae & 24 & 49 & 1 & 9 \\
\hline & Mollusca & & & & & \\
\hline 179 & Anodontia sp. & Lucinidae & - & - & - & 7 \\
\hline 180 & Arcopsis sp. & Arcidae & - & 1 & - & - \\
\hline 181 & Amygdalum sp. & Mytilidae & - & - & - & 1 \\
\hline 182 & Azorinus sp. & Solecurtidae & - & - & - & 1 \\
\hline 183 & Barrimysia sp. & Montacutidae & 1 & - & - & - \\
\hline 184 & Bulla sp. & Bullidae & 3 & - & - & - \\
\hline 185 & Cardomya (Cardomya) sp. & Cuspidariidae & - & - & - & 1 \\
\hline 186 & Chlamys sp. & Pectinidae & - & - & - & 1 \\
\hline 187 & Corbula sp. & Corbulidae & 1 & - & - & - \\
\hline 188 & Corbula (Notocorbula) sp. & Corbulidae & - & - & 2 & 1 \\
\hline 189 & Cylichna sp. & Cylichnidae & - & - & 1 & - \\
\hline 190 & Chaetodermomorpha & Chaetodermatidae & - & - & 2 & 2 \\
\hline 191 & Dentalium sp. & Dentaliidae & - & 1 & - & 1 \\
\hline 192 & Exotica (Exotica) sp. & Tellinidae & - & 1 & 1 & - \\
\hline 193 & Frigidocardium sp. & \begin{tabular}{|l|} 
Cardiidae \\
\end{tabular} & - & - & - & 1 \\
\hline 194 & Gari (Gari) sp. & Psammobiidae & - & - & - & 2 \\
\hline 195 & Gastrochaena sp. & Gastrochaenidae & - & - & - & 2 \\
\hline 196 & Hexacorbula sp. & Corbulidae & 1 & 1 & - & 1 \\
\hline 197 & Laternula sp. & Laternulidae & 1 & - & - & - \\
\hline 198 & Linga (Bellucina) sp. & \begin{tabular}{|l|} 
Lucinidae \\
\end{tabular} & - & - & 1 & - \\
\hline 199 & Modiolus sp. & Mytilidae & - & - & - & 4 \\
\hline 200 & Nuculana (Nuculana) sp. & Nuculanidae & - & 2 & 3 & - \\
\hline 201 & Nucula sp. & \begin{tabular}{|l|} 
Nuculidae \\
\end{tabular} & - & 1 & - & - \\
\hline 202 & Oliva sp. & Olividae & 1 & - & - & - \\
\hline 203 & Pitar sp. & Veneridae & - & - & - & 1 \\
\hline 204 & Psammotetra (Psammotetra) sp. & Tellinidae & - & 1 & - & - \\
\hline 205 & Ringicula sp. & Ringiculidae & - & $\cdot$ & 1 & 1 \\
\hline 206 & Solen sp. & Solenidae & 1 & - & - & - \\
\hline 207 & Tellina (Semelangulus) sp. & Tellinidae & 2 & 2 & 6 & 29 \\
\hline 208 & Tellina (Merisca) sp. & Tellinidae & - & 1 & - & 5 \\
\hline 209 & Tellina (Angulus) sp. & Tellinidae & - & 1 & - & - \\
\hline 210 & Tellina (Acropagia) sp. & Tellinidae & - & - & - & 3 \\
\hline 211 & Tellina (Cyclotellina) sp. & Tellinidae & - & - & - & 6 \\
\hline 212 & Timoclea (Glycodonta) sp.2 & Veneridae & 1 & - & - & - \\
\hline \multirow[t]{2}{*}{213} & Timoclea (Timoclea) sp. & Veneridae & - & - & - & 1 \\
\hline & Echinodermata & & & & & \\
\hline 214 & Amphioplus (Amphioplus) sp. & Amphiuridae & 1 & - & - & - \\
\hline
\end{tabular}


Appendix 1. (continued)

\begin{tabular}{|c|c|c|c|c|c|c|}
\hline No. & Species & Family/Order & Layer I & Layer II & Layer III & Layer IV \\
\hline 215 & Amphioplus sp. & Amphiuridae & - & 1 & 1 & 2 \\
\hline 216 & Amphioplus (Lymanella) sp. & Amphiuridae & - & - & - & 1 \\
\hline 217 & Amphiura sp. & Amphiuridae & 1 & 6 & 8 & 4 \\
\hline 218 & Amphiuridae & Amphiuridae & 4 & 3 & 3 & 7 \\
\hline 219 & Holothuria sp. & Holothuriidae & - & - & - & 6 \\
\hline 220 & Laganum sp. & Laganidae & - & - & - & 2 \\
\hline 221 & Lovenia sp. & Loveniidae & - & 2 & - & - \\
\hline 222 & Lovenia subcarinata & Loveniidae & - & - & 2 & - \\
\hline 223 & Loveniidae & Loveniidae & - & - & 5 & - \\
\hline 224 & Synaptidae & Synaptidae & 11 & 15 & - & 1 \\
\hline 225 & Spatangoidea & Loveniidae & 1 & - & - & - \\
\hline \multirow[t]{2}{*}{226} & Temnopleuridae & Temnopleuridae & - & - & - & 1 \\
\hline & Miscellaneous Group & & & & & \\
\hline 227 & Apionsoma sp. & Phascolosomatidae & 96 & 74 & 15 & 33 \\
\hline 228 & Aspidosiphon sp. & Aspidosiphonidae & - & - & - & 1 \\
\hline 229 & Lingula sp. & Lingulidae & - & - & - & 4 \\
\hline 230 & Sipunculus sp. & Sipunculidae & 2 & $\cdot$ & - & 1 \\
\hline 231 & Ascidiacea 4 & Ascideacea & 1 & 1 & - & 1 \\
\hline 232 & Actinaria & Actinaria & 5 & - & - & 1 \\
\hline 233 & Athecata C & Nephtyidae & - & $\cdot$ & - & 1 \\
\hline 234 & Athecata D & Nephtyidae & - & - & - & 1 \\
\hline 235 & Athecata $\mathrm{E}$ & Nephtyidae & 1 & 3 & - & 10 \\
\hline 236 & Dendronephthya & Nephtyidae & - & - & - & 1 \\
\hline 237 & Hydrozoa & Plumaridae & - & 5 & - & - \\
\hline 238 & Phascolion sp. & Phascolionidae & - & - & - & 7 \\
\hline 239 & Stycalium sp. & Virgulariidae & 1 & - & - & - \\
\hline 240 & Stycalium sp.2 & Virgulariidae & - & 1 & - & - \\
\hline 241 & Sponge & Porifera & - & - & - & 1 \\
\hline 242 & Themites sp. & Themistidae & - & - & 1 & - \\
\hline 243 & Unidentifed sp.1 & & - & - & 9 & 4 \\
\hline 244 & Unidetified sp.13 & & - & 1 & - & - \\
\hline 245 & Unidentified sp.21 & & - & 1 & - & - \\
\hline 246 & Amblychaeturichtys hexenema & Gobiidae & 1 & - & - & - \\
\hline 247 & Apocryptodon sp. & Gobiidae & - & 1 & 1 & - \\
\hline 248 & Bregmaceros nectabanus & Bregmacerotidae & - & 3 & 11 & - \\
\hline 249 & Bregmaceros sp. & Bregmacerotidae & - & 1 & 1 & - \\
\hline 250 & Bathygobius sp. & Gobiidae & - & - & - & 1 \\
\hline 251 & Ctenopauchen microcephalus & Gobiidae & 2 & 2 & 2 & - \\
\hline 252 & Glossogobius sp. & Gobiidae & - & - & - & 1 \\
\hline 253 & Gobiidae & Gobiidae & 1 & - & - & - \\
\hline 254 & Parachaeturichtys polynema & Gobiidae & - & 4 & - & - \\
\hline 255 & Taenioides rubicundus & Gobiidae & - & 2 & 1 & - \\
\hline 256 & Valenciennea sp. & Gobiidae & 1 & 2 & - & - \\
\hline & Nemertea & & & & & \\
\hline 257 & Enopla 2 & Nemertea & 1 & - & - & - \\
\hline 258 & Enopla 5 & Nemertea & 92 & 36 & 7 & 1 \\
\hline 259 & Enopla 10 & Nemertea & 15 & 1 & 2 & - \\
\hline 260 & Enopla 11 & Nemertea & - & - & 1 & - \\
\hline 261 & Lineidae 1 & Lineidae & 5 & 10 & 2 & 7 \\
\hline 262 & Lineidae 2 & Lineidae & 16 & 7 & 18 & 10 \\
\hline 263 & Lineidae 3 & Lineidae & 34 & 42 & 22 & 21 \\
\hline 264 & Lineidae 7 & Lineidae & - & - & 2 & - \\
\hline 265 & Lineidae 15 & Lineidae & - & - & 1 & - \\
\hline 266 & Lineidae 17 & Lineidae & - & - & 1 & - \\
\hline
\end{tabular}

